\title{
Purification and Characterization of a Trypsin Inhibitor from Mouse Seminal Vesicle Secretion
}

\author{
Min-Long Lai, ${ }^{*}$ Shun-Wen Chen, $\dagger$ and Yee-Hsiung Chen ${ }^{*, \dagger}, 1$ \\ *Institute of Biochemical Science, College of Science, National Taiwan University; and $\dagger$ Institute of Biological Chemistry, \\ Academia Sinica, Taipei, 10764 Taiwan, Republic of China
}

\begin{abstract}
A Kazal-type trypsin inhibitor in mouse seminal vesicle secretion was purified to homogeneity via a series of purification steps including ammonium sulfate fractionation, affinity chromatography on a trypsin Affi-Gel 10 column, and HPLC on a reverse phase $C_{4}$ column. It was shown to be a weak basic protein with an isoelectric point of 8.7 and to contain no carbohydrate. The protein had a specific activity of $184 \mathrm{U} / \mathrm{mg}$ protein in the inhibitory effect on the trypsin digestion of $\mathrm{N}$-benzoyl-Pro-PheArg-p-nitroanilide. Analysis of the kinetic data for the trypsin digestion of $N$-benzoyl-Phe-Val-Arg 7 -amido4-methylcoumarin revealed that the protein was a competitive inhibitor with an inhibitory constant $\left(K_{i}\right)$ of 0.15 nM. The molecular mass of the protein was determined to be $7 \mathrm{kDa}$ by both gel chromatography and clcetrophoresis. Results of direct amino acid determinations indicated that this protein corresponded to the reading frame of MP12 cDNA identified from mouse prostate. We found that cleavage only at the reactive site of this protein $\left(\mathrm{Arg}^{19}-\mathrm{Ile}^{20}\right)$ resulted in its denaturation. (c) 1991 Academic Press, Inc.
\end{abstract}

The seminal vesicles present in most adult male mammals secrete a group of proteins that constitute a major portion of seminal plasma $(1,2)$. The biological significance of these proteins in mammalian reproductive physiology is currently obscure. It was found that extirpation of seminal vesicles from a mouse greatly reduced fertility $(3,4)$. Recently, seven and five major proteins have been identified from mouse and rat seminal vesicle secretion (SVS). ${ }^{2}(5,6)$. The genetic expression of some of these

\footnotetext{
${ }^{1}$ To whom correspondence should be addressed. Fax: (02) 363-5038.

${ }^{2}$ Abbreviations used: MSVS, mouse seminal vesicle secretion; TI, trypsin inhibitor; PSTI, pancreatic secretory trypsin inhibitor; PI, protease inhibitor; SDS, sodium dodecyl sulfate; PAGE, polyacrylamide gel electrophoresis; IEF, isoelectric focusing; PCR, polymerase chain reaction.
}

proteins has been shown to be dependent on the presence of testosterone (6-8).

Protease inhibitors (PIs) have a physiological function other than the inhibition of protease activity (9). Existence of PIs in sex accessory tissues of mammals is well known (10-12). They are believed to be important for protection of genital tract epithelium against proteolytic damage (13) and/or have a regulatory role in the fertilization process $(14,15)$. Hence, the study of PIs in the genital tract is an important subject of reproductive biology.

A cDNA (MP12) which codes for a Kazal-type PI has heen identified in the mouse ventral prostate by molecular cloning (16). Androgen-dependent expression of this PI mRNA as probed with MP12 cDNA has been observed in male sex accessory tissues including ventral prostate, seminal vesicle, and coagulating gland, but it is expressed constitutively in the pancreas (16). Meanwhile, a PI with a molecular weight of $12 \mathrm{kDa}$ (P12) has been identified in the mouse ventral prostate, and it was suggested that MP12 cDNA corresponds to the P12 protein (17). In the present study, we purified and characterized one TI from MSVS. This TI is a basic polypeptide of 57 amino acid residues, which is similar to rat PSTI-II but different from rat PSTI-I (9) on the basis of molecular size. It is not a glycoprotein in nature, which is different from the P12 protein which is believed to be a glycoprotein (17). We confirmed further that the primary structure of this TI is identical to that deduced from MP12 cDNA.

\section{EXPERIMENTAL}

Materials. Affi-Gel 10 was purchased from Bio-Rad Laboratories (Richmond, CA). $N$-Benzoyl-Pro-Phe-Arg- $p$-nitroanilide $\mathrm{HCl}, N$-benzoyl-Phe-Val-A rg 7-amido-4-methylcoumarin, bovine pancreatic trypsin, and soybean trypsin inhibitor were obtained from Sigma Chemical Co., (St. Louis, MO). Markers for IEF and thin layer ampholine PAGE plate were procured from Sartorius Gmbh (FRG). Sephadex G-50 was obtained from Pharmacia (Uppsala, Sweden). AMV reverse transcriptase and T7 DNA polymerase sequencing system were purchased from Promega (Madison, WI). T4 DNA ligase was obtained from Bethesda Re- 
TABLE I

Purification of TI from MSVS ${ }^{a}$

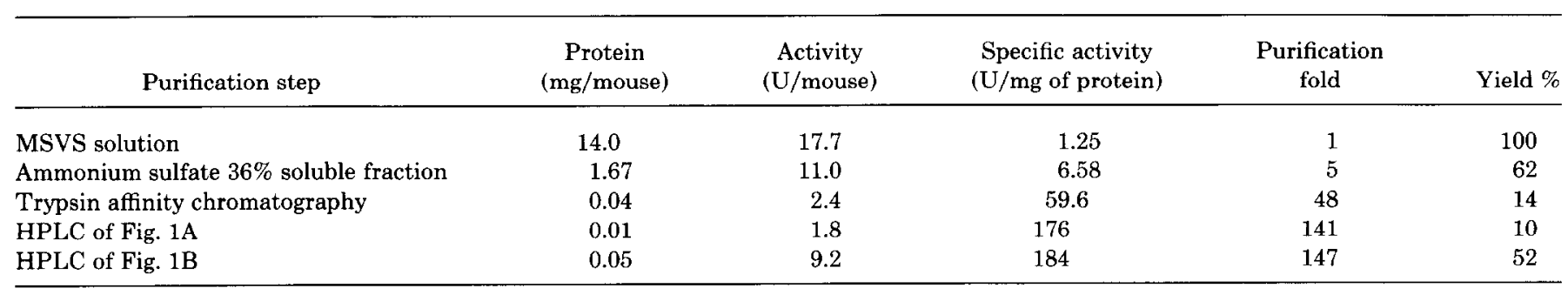

${ }^{a}$ Data were the average of 20 mice, 9 weeks old. See text for details.

search Laboratories (Gaithersburg, MD). Restriction enzymes such as $B a m H I, E c o R I$, and $S m a I$ were purchased from Boehringer Mannheim Gmbh (FRG). Taq polymerase was obtained from Perkin-Elmer Cetus Co., (Norwalk, CT). Geneclean kit was purchased from Bio 101 Inc. (La Jolla, CA). All chemicals were reagent grade from commercial sources.

Extraction of TI from MSVS. The seminal vesicles of mature male mice (ICR) killed by cervical dislocation were carefully dissected to frec them from the adjacent coagulating gland, and the secretion collected from 100 mice was expressed directly into $100 \mathrm{ml}$ of ice cold $5 \%$ acetic acid. After stirring at $4^{\circ} \mathrm{C}$ for $30 \mathrm{~min}$, the solution became clear. The solution was fractionated in $36 \%$ saturation of ammonium sulfate, and the mixture was adjusted to $\mathrm{pH} 2.0$ with $6 \mathrm{~N} \mathrm{HCl}$. The precipitating material was removed by centrifugation at $8000 \mathrm{~g}$ for $20 \mathrm{~min}$. The solution was passed through a glass filter to remove lipid and dialyzed against $0.5 \%$ acetic acid and lyophilized.

SDS-PAGE and IEF. Proteins were resolved by SDS-PAGE on a $15 \%$ gel slab $(15 \times 12 \times 0.075 \mathrm{~cm})$ according to the method of Schägger et al. (18). IEF on a thin layer ampholine PAGE plate ( $\mathrm{pH}$ range 3-10) was performed by a LKB multiphor unit. The cathodic fluid consisted of $0.44 \% \mathrm{Arg}-0.06 \%$ Lys, which was adjusted to $\mathrm{pH} 10$ by the addition of ethylenediamine. The anodic fluid contained $0.33 \%$ Asp- $0.37 \%$ Glu at $\mathrm{pH}$ 3.0. Focusing was conducted for $4 \mathrm{~h}$ at a constant power of 2.0 W with initial current of $10 \mathrm{~mA}$ and a voltage maximum of $1.7 \mathrm{kV}$.

Immobilization of trypsin. Coupling of protein to Affi-Gel 10 was according to the supplier's specification. At $4^{\circ} \mathrm{C}, 5 \mathrm{mg}$ of trypsin in 1.0 $\mathrm{ml}$ of $5 \mathrm{mM}$ phosphate- $0.4 \mathrm{M} \mathrm{NaCl}$ at $\mathrm{pH} 7.9$ was mixed overnight with an equal volume of Affi-Gel 10, which was washed with the same buffer beforehand. Ethanolamine was then added to the gel mixture to a final concentration of $1.0 \mathrm{M}$ to stop the coupling reaction. It was determined that $1 \mathrm{ml}$ of the trypsin affinity gel could absorb $150 \mu \mathrm{g}$ of soybean trypsin inhibitor.

Amino acid analysis and sequencing. Protein was hydrolyzed in the vapor phase of $7.0 \mathrm{M} \mathrm{HCl}$ containing $10 \%$ trifluoroacetic acid and $0.1 \%$ phenol at $158^{\circ} \mathrm{C}$ for $30 \mathrm{~min}$, according to the method of Tsugita et al. (19). Amino acid composition was determined by the conventional method of Spackman et al. (20) on a Beckman System 6300 high performance analyzer. The amount of tryptophan was determined by a UV absorption method. The amino acid sequence was determined by automated Edman degradation with a gas-phase microsequenator (477A protein sequencer with on line 120A analyzer, Applied Biosystems, Foster City, CA).

Sugar analysis. Protein was digested with $3.0 \mathrm{M}$ trifluoroacetic acid in a siliconized tube at $100^{\circ} \mathrm{C}$ for $6 \mathrm{~h}$. The digested sample was evaporated to dryness, redissolved in an adequate amount of water, and subjected to chromatography on a Dionex Bio LC System (Dionex Corp., Sunnyvale, $\mathrm{CA}$ ) attached to a pulse amperometric detector.

Assay of TI activity. $\quad N$-Benzoyl-Pro-Phe-Arg-p-nitroanilide $\mathrm{HCl}$ was used as substrate and hydrolysis of the substrate was followed by the change in absorbance at $405 \mathrm{~nm}(21,22)$. One enzyme unit corresponded to the hydrolysis of $1 \mu \mathrm{mol}$ of substrate per minute by bovine pancreatic trypsin. The activity of TI was based on its inhibitory effect on the digestion of substrate by trypsin. Trypsin and TI were mixed and preincubated for $5 \mathrm{~min}$ before the addition of substrate. One inhibitor unit corresponded to the reduction of one enzyme unit. The specific activity of TI was expressed in inhibitor units per milligram of protein.

Kinetic analysis. The trypsin digestion of $N$-benzoyl-Phe-Val-Arg 7-amido-4-methylcoumarin was followed by the change in fluorescence at $460 \mathrm{~nm}$ with excitation wavelength at $380 \mathrm{~nm}$. The kinetic data for the inhibitory effect of TI on the trypsin activity were analyzed by Dixon's plot for determining the inhibitory constant $\left(K_{i}\right)$ of a tight binding enzyme inhibitor $(23,24)$ :

$$
K_{i}\left(1+[\mathrm{S}] / K_{m}\right)=K
$$

where $K_{m}$ may be regarded as a "pseudo-equilibrium constant" and $K$ is the distance between two neighboring intersection points on the abscissa of the plot of the velocity of the enzyme reaction (ordinate) vs inhibitor concentration (abscissa). A plot of $K$ against [S] will be a straight line of which the intersection with the vertical axis gives $K_{i}$ and that with the base line gives $K_{m}$.

RNA isolation and cDNA preparation. Total cellular RNA was isolated from adult MSV according to a previous method (25). Singlestranded $\mathrm{cDNAs}$ were prepared on the polyadenylated fraction of MSV RNA by standard procedure (25) using AMV reverse transcriptase.

Polymerase chain reaction, cloning and analysis. Based on MP12 cDNA of mouse ventral prostate, we synthesized one oligonucleotide of CCCAGATCTTCGACAATGAAGGT, which is in the $5^{\prime}$-noncoding region, and the other oligonucleotide of CCCACGTTGCCTTTCATTACGG, which is complementary to the $3^{\prime}$-untranslated region (see Fig. 5). Those two oligonucleotides were employed as the primer pair for PCR, which amplified the single-stranded cDNAs of MSV with Taq polymerase for 30 cycles: $94^{\circ} \mathrm{C}, 1.5 \mathrm{~min} ; 40^{\circ} \mathrm{C}, 2.0 \mathrm{~min} ; 72^{\circ} \mathrm{C}, 3.0 \mathrm{~min}$. The reaction mixture was subjected to electrophoresis on a $1.8 \%$ agarose gel. The amplified DNA, which was extracted from the gel with a Geneclean kit, was ligated to pUC19 via a $S m a I$ site and introduced into Escherichia coli strain DH5 $\alpha$ using a transformation technique (26). Positive clones containing the cDNA insert were confirmed by $E c o$ RIBamHI digestion. The cDNAs concerned were sequenced by the dideoxy T7 DNA polymerase technique using either oligonucleotide of the primer pair employed for PCR as the primer (27). Each base was determined at least three times in both orientations.

\section{RESUI.TS}

\section{Purification of MSVS TI}

Table I summarizes the steps for the purification. MSVS was soluble in $5 \%$ acetic acid. The soluble MSVS was fractionated initially by $36 \%$ saturation of ammonium 

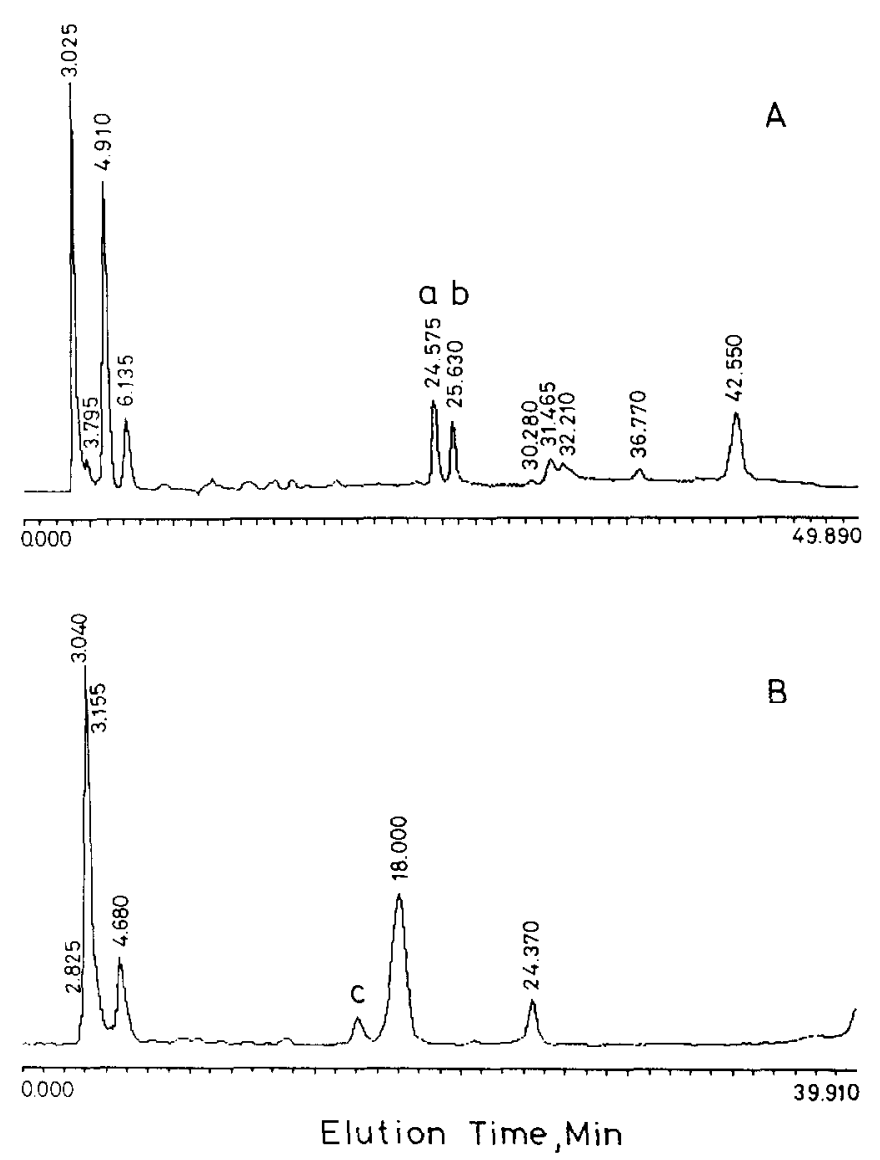

FIG. 1. Purification of MSVS TI by reverse-phase HPLC. Chromatography was carried out on a Waters $\mathrm{C}_{4} 300 \mathrm{~A}$ column $(3.9 \times 300 \mathrm{~mm})$ equilibrated with $0.1 \%$ TFA, and the effluent was monitored at $280 \mathrm{~nm}$. (A) The TI fraction isolated from affinity chromatography on a trypsin Affi-Gel 10 column (see text for details) was applied, and the column was eluted with a linear gradient of $0-60 \%$ acetonitrile at a flow rate of $1.0 \mathrm{ml} / \mathrm{min}$ for $50 \mathrm{~min}$. (B) The soluble fraction of MSVS in $36 \%$ saturation of ammonium sulfate (see text for details) was subjected directly to chromatography, and the column was eluted with a linear gradient of $15-40 \%$ acetonitrile at a flow rate of $1 \mathrm{ml} / \mathrm{min}$ for $40 \mathrm{~min}$. Peaks a, $\mathrm{b}$, and $\mathrm{c}$ are denoted.

sulfate precipitation at $\mathrm{pH} 2.0$. Around $62 \%$ of total TI activity remained in the solution. Further purification by affinity chromatography on a trypsin Affi-Gel 10 column preequilibrated with $0.4 \mathrm{M} \mathrm{NaCl}-0.1 \mathrm{M}$ Tris at $\mathrm{pH} 7.9$ gave a TI fraction which was eluted from the column with $0.1 \mathrm{M}$ glycine at $\mathrm{pH} 3.0$ (not shown). Only $14 \%$ of the total TI activity was recovered from the column. Subjection of the TI fraction to HPLC on a reverse phase $\mathrm{C}_{4}$ $300 \mathrm{~A}$ column gave six major peaks (Fig. 1A). TI activity appeared only in peak a. Direct resolution of the proteins in the ammonium sulfate solution described above by HPLC greatly improved the yield of TI, which appeared at peak $\mathrm{c}$ shown in Fig. 1B. Around $52 \%$ of the total 'II activity was recovered with this procedure. However, repeated HPLC was necessary to obtain pure TI. It should be mentioned that the purity of TI was increased 147- fold after HPLC. The specific activity of 'TI thus purified was $184 \mathrm{U} / \mathrm{mg}$ of protein. Estimation based on the activity indicated that TI comprised $0.7 \%$ of the soluble MSVS proteins.

\section{Preliminary Characterization of MSVS TI}

MSVS was resolved by SDS-PAGE into seven major protein bands (Fig. 2A, lane 2). In accordance with the nomenclature of Chen et al. (6), these bands were labeled I-VII in decreasing order of size.

The absorbance, $E_{1 \mathrm{~cm}}^{1 \%}$, of peak a protein (Fig. 1A) was determined to be rather low at 4.2. Sugar analysis revealed no carbohydrate present in the protein. A single band of $7 \mathrm{kDa}$ with the isoelectric point at 8.7 was detected on analysis of the protein by both SDS-PAGE (Fig. 2A, lane 3) and IEF in $\mathrm{pH} 3.0-10.0$ (Fig. 2B, lane 2), indicating that the protein had been purified to homogeneity and was distinct from the main proteins (cf. lanes 2 and 3 of Fig. 2A). The molecular weight of the protein was determined from the partition coefficient, $K_{\mathrm{av}}$, in the gel chromatography (Fig. 3) agreed with that estimated from SDS-PAGE. The $K_{\text {av }}$ determined from the position tracing for TI activity in the gel chromatography of the soluble MSVS showed no difference from that of peak a protein, suggesting no association between peak a protein and other protein(s) in MSVS.
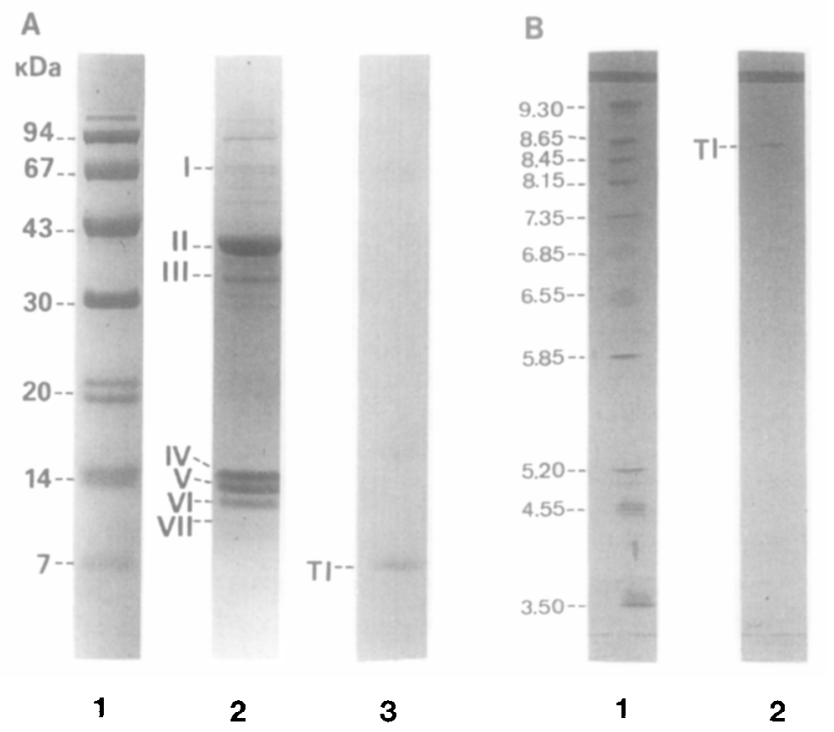

FIG. 2. (A) Protein components of soluble MSVS. A suitable amount of protein was subjected to SDS-PAGE on a $15 \%$ slab gel $(15 \times 12$ $\times 0.075 \mathrm{~cm}$ ). (1) Protein standard: phosphorylase b (94 kDa), bovine serum albumin $(67 \mathrm{kDa})$, ovalbumin $(43 \mathrm{kDa})$, carbonic anhydrase $(30$ $\mathrm{kDa}$ ), soybean trypsin inhibitor (20 kDa), $\alpha$-lactalbumin ( $14 \mathrm{kDa})$, snake venom cardiotoxin (7 kDa); (2) MSVS $(50 \mu \mathrm{g})$; (3) peak a protein of Fig. $1(10 \mu \mathrm{g})$. (B) Isoelectric focusing patterns: (1) protein markers; (2) peak a protein of Fig. $1(5.0 \mu \mathrm{g})$. IEF was performed in thin layer ampholine PAGE plate ( $\mathrm{pH} 3-10)$. Protein patterns were visualized after staining the gels with Coomassie blue. The isoelectric point of peak a protein appeared at 8.7 . 


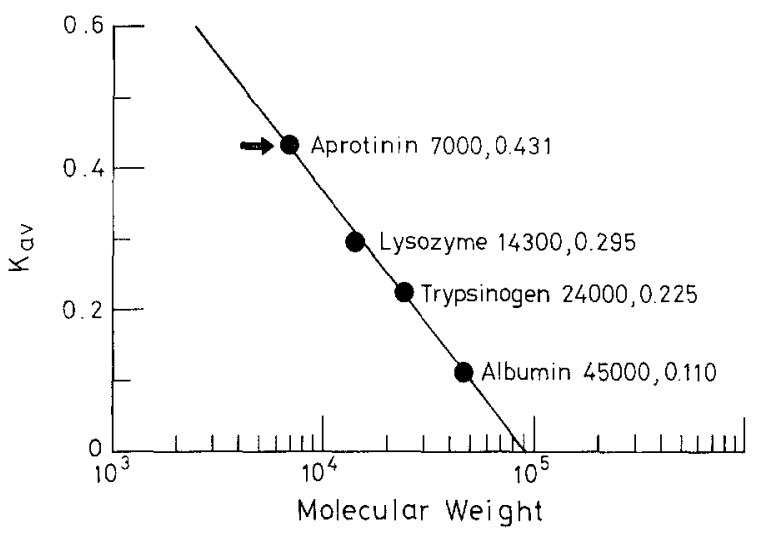

FIG. 3. Molecular weight determination of MSVS TI by gel filtration. Peak a protein of Fig. 1, soluble MSVS, and marker proteins were applied individually to a Sephadex G-50 column $(1.2 \times 100 \mathrm{~cm})$. The column was eluted with Tris $0.1 \mathrm{M}$ at $\mathrm{pH} 7.8$. Trypsin inhibitor activity was measured. The partition coefficient of each protein was calculated from its elution volume $\left(V_{e}\right)$, void volume $\left(V_{o}\right)$, and total bed volume $\left(V_{t}\right)$ of the gel in accordance with $K_{\mathrm{av}}=\left(V_{\mathrm{e}}-V_{\mathrm{o}}\right) /\left(V_{\mathrm{t}}-V_{\mathrm{o}}\right)$. The molecular weight and $K_{\mathrm{av}}$ of each marker protein are shown in the figure. The $K_{\mathrm{av}}$ of peak a protein as denoted with an arrow in the figure was estimated to be 0.43 , which corresponded to a molecular weight of $7 \mathrm{kDa}$. The same molecular weight was determined from the trypsin inhibitor activity tracing on the chromatogram of soluble MSVS.

Direct analysis of amino acid composition (Table II) indicated that peak a protein contained no tryptophan and only a small amount of tyrosine, which accounts for the low absorbance of this protein at $280 \mathrm{~nm}$. The protein was found to have a net excess of basic residues which could give rise to the slightly basic isoelectric point. The amino acid composition data generated directly from the analysis of protein were generally compatible with the putative mature protein derived from MP12 cDNA (16). It was of interest to note that peak $b$ protein, which showed no trypsin inhibitory activity, shared with peak a protein the same amino acid composition (not shown).

Having measured the inhibitory activity of peak a protein on the trypsin digestion of $N$-benzoyl-Phe-Val-Arg 7-amido-4-methylcoumarin in 2-100 $\mu \mathrm{M}$ (one case is shown in Fig. 4A), we found that the $K$ in Eq. [1] varied with the substrate concentration. This behavior indicated that peak a protein inhibited the trypsin catalysis competitively according to the explanation of Dixon (23). The plot based on Eq. [1] as shown in Fig. $4 \mathrm{~B}$ gave $K_{i}$ and $K_{m}$ to be $0.15 \mathrm{nM}$ and $50 \mu \mathrm{M}$, respectively.

\section{Primary Structure of MSVS TI}

More than one type of PI with different molecular size may exist in one organ of an animal. For instance, two types of PSTIs are present in porcine and rat pancreatic juice $(9,28,29)$. Rat PSTI-I consists of 61 and PSTI-II of 56 amino acid residues (9). They are highly homologous and show the same trypsin inhibitory activity but have different physiological functions. These two inhibitors originate from different genes, but their cDNAs have identical $5^{\prime}$-noncoding regions and nearly identical $3^{\prime}$ noncoding regions $(30,31)$, suggesting that $5^{\prime}$-noncoding regions as well as $3^{\prime}$-noncoding regions of PSTI-related cDNAs of one organ may be highly conserved. Having this background in mind, we amplified the cDNAs of MSV by PCR using oligonucleotides corresponding to $5^{\prime}$ - and $3^{\prime}$-noncoding region of MP12 as primer pair (see Experimental section). Fourtcen colonies containing the amplified cDNAs were identified from the transformed $E$. coli strain DH5 $\alpha$. The 14 cDNA inserts contained the same number of nucleotides ( $309 \mathrm{bp}$ ) and showed the same nucleotide sequences, which confirmed completely those in MP 12 cDNA (369 bp). Apparently, a PI mRNA corresponding to MP12 cDNA did express in MSV. The nucleotide sequences of the amplified cDNA and MP12 cDNA and the deduced amino acid sequence are shown in Fig. 5. Further analyses of peak a, b, and c proteins purified from HPLC (Fig. 1) by direct determination of a portion of the primary structure were undertaken. We found no evidence of modification of amino acid residues during sequence analysis from the results of sequence analysis. Results of amino acid determinations were aligned with the cDNA-derived sequence (Fig. 5).

Automated Edman degradation of either peak a or peak c protein (both were biologically active) for 30 cycles gave reliable data. The same amino acid was identified for the

TABLE II

Amino Acid Composition of MSVS TI

\begin{tabular}{lccc}
\hline Amino acid & mol $(\%)$ & mol/mol of protein & \\
\hline Asx & 8.9 & 5.12 & Deduced value $^{b}$ \\
Glx & 7.6 & 4.37 & $5^{c}$ \\
Ser & 4.3 & 2.46 & $4^{d}$ \\
Thr & 4.6 & 2.62 & 1 \\
Gly & 10.4 & 5.98 & 3 \\
Ala & 9.3 & 5.33 & 6 \\
Arg & 6.7 & 3.82 & 5 \\
Pro & 6.9 & 3.95 & 4 \\
Val & 8.6 & 4.91 & 4 \\
Met & 0.3 & 0.18 & 5 \\
Ile & 5.2 & 2.99 & 0 \\
Leu & 3.7 & 2.11 & 4 \\
Trp & 0.3 & 0.16 & 2 \\
Phe & 2.2 & 1.28 & 0 \\
Cys & $9.2^{e}$ & $5.28^{e}$ & 1 \\
Lys & 7.1 & 4.09 & 6 \\
His & 1.7 & 1.01 & 4 \\
Tyr & 2.8 & 1.63 & 1 \\
& & 57.29 & 2 \\
\hline
\end{tabular}

\footnotetext{
${ }^{a}$ Average of four determinations based on a molecular weight of 7000 Da.

${ }^{b}$ Value derived from the MP12 cDNA sequence.

${ }^{c}$ Three aspartic acid and two asparagine.

${ }^{d}$ Four glutamic acid.

${ }^{e}$ Cysteic acid.
} 
A

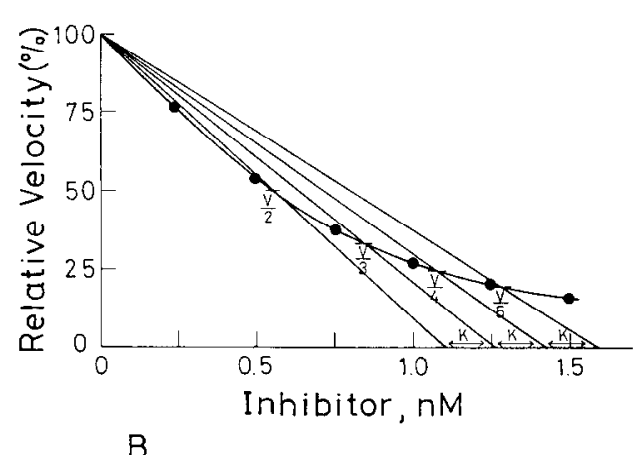

B

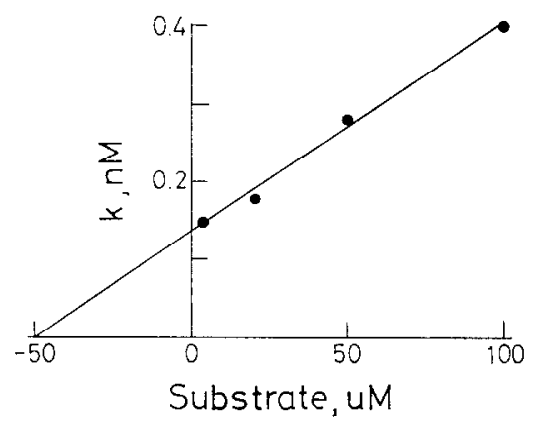

FIG. 4. Effect of MSVS TI on trypsin kinetics. (A) Trypsin at 1.0 $\mathrm{nM}$ and peak a protein (Fig. 1) were incubated at $25^{\circ} \mathrm{C}$ for $5 \mathrm{~min}$ before adding the substrate of $\mathrm{N}$-benzoyl-Phe-Val-Arg 7-amido-4-methylcoumarin to a final concentration of $20 \mu \mathrm{M}$. The relative velocity was expressed by using the velocity measured in the absence of inhibitor as $100 \%$. (B) The plot of distance $K$ vs substrate concentration according to Eq. [1].

two proteins at each cycle, showing that they are the same protein molecule. The amino acid determinations confirmed both Ala as the $\mathrm{NH}_{2}$-terminal residue and the reading frame of MP12 cDNA. The $\mathrm{NH}_{2}$-terminal sequence analysis of peak $b$ protein for 30 cycles gave reliable data also. Two predominant amino acids could be detected at each of the first 19 cycles, and a single amino acid could be detected at each of the last eleven cycles (Table III). The actual yields of the two sequences in an individual cycle were such that both components appeared to be present in nearly equal amounts. One of the two sequences could readily be interpreted as representing the $\mathrm{NH}_{2}$-terminal sequence of peak a protein while the other was found to be a new sequence, which confirmed residues 20-49 of the reading frame of MP12 cDNA. These data along with the amino acid composition data suggested that peak $b$ protein was produced from the digestion by the immobilized trypsin at the peptide bond of $\mathrm{Arg}^{19}-\mathrm{Ile}^{20}$ of peak a protein. In summary, 49 out of 57 amino acid residues in the putative mature protein predicted from MP12 cDNA were confirmed by direct protein analysis.

\section{DISCUSSION}

According to the alignment of homologous protease inhibitors (16), MSVS TI shows a high degree of sequence similarity with the vertebrate Kazal-type PIs. Our results suggest that one type of PI similar to rat PSTI-II is likely to be translationally produced in MSV. We have not found yet another type of PI similar to rat PSTI-I in MSV. The vertebrate Kazal-type PIs may possess similar, although not identical, main chain conformation (16). They give "temporary inhibition" to the related proteinases by a common mechanism $(15,32)$. In each inhibitor molecule there exists on the surface one peptide bond, the reactive site, which combines with the enzyme in a substrate-like manner and serves as a substrate for the enzyme. In the absence of tertiary structure for MSVS TI, which was shown to be a competitive inhibitor, we superimposed the primary structure of this protein onto the three-dimensional structure of porcine PSTI in the complex formed by PSTI and trypsinogen (33) and made some educated guesses. Residues from $\mathrm{His}^{11}$ to $\mathrm{Asp}^{22}$ of MSVS TI may be the primary origin which is involved in the major polar interaction with trypsin, and the reactive site peptide bond is apparently at $\mathrm{Arg}^{19}-\mathrm{Ile}^{20}$. The basic sequence of $\mathrm{Arg}^{43}$ $\mathrm{Lys}^{44}-\mathrm{Arg}^{45}$, which plays an important role in the regulation of temporary inhibition according to the study of

TAB̈LE III

The $\mathrm{NH}_{2}$-Terminal Sequence Analysis of Peak b Protein of Fig. 1A

\begin{tabular}{|c|c|c|c|}
\hline Step & Amino acids & $\mathrm{NH}_{2}$ terminus of MSVS $\mathrm{TI}^{a}$ & New sequence \\
\hline 1 & Ala, Ile & Ala & Ile \\
\hline 2 & Lys, Tyr & Lys & Tyr \\
\hline 3 & Val, Asp & Val & Asp \\
\hline 4 & Thr, Pro & Thr & Pro \\
\hline 5 & Gly, Val & Gly & Val \\
\hline 6 & Lys - & Lys & - \\
\hline 7 & Glu, Gly & Glu & Gly \\
\hline 8 & Ala, Thr & Ala & Thr \\
\hline 9 & Ser, Asp & Ser & Asp \\
\hline 10 & - Gly & - & Gly \\
\hline 11 & His, Ile & His & Ile \\
\hline 12 & Asp, Thr & Asp & Thr \\
\hline 13 & Ala, Tyr & Ala & Tyr \\
\hline 14 & Val, Ala & Val & Ala \\
\hline 15 & Ala, Asn & Ala & Asn \\
\hline 16 & Gly, Glu & Gly & Glu \\
\hline 17 & -- & - & - \\
\hline 18 & Pro, Val & Pro & Val \\
\hline 19 & Arg, Leu & Arg & Leu \\
\hline 20 & - & Ile & - \\
\hline 21 & Phe & Tyr & Phe \\
\hline 22 & Glu & Asp & Glu \\
\hline 23 & Asn & Pro & Asn \\
\hline 24 & Arg & Val & Arg \\
\hline 25 & Lys & - & Lys \\
\hline 26 & Arg & Gly & Arg \\
\hline 27 & Ile & Thr & Ile \\
\hline 28 & Glu & Asp & Glu \\
\hline 29 & Pro & Gly & Pro \\
\hline 30 & Val & Ile & Val \\
\hline
\end{tabular}

${ }^{a}$ The $\mathrm{NH}_{2}$-terminal sequence analysis of peak a protein of Fig. 1A. 
A

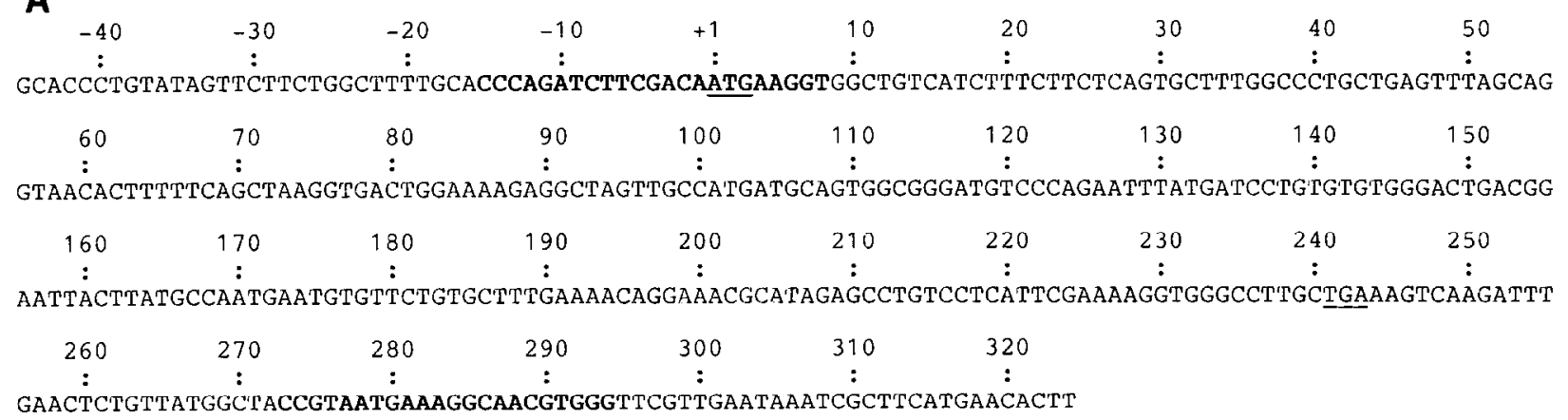

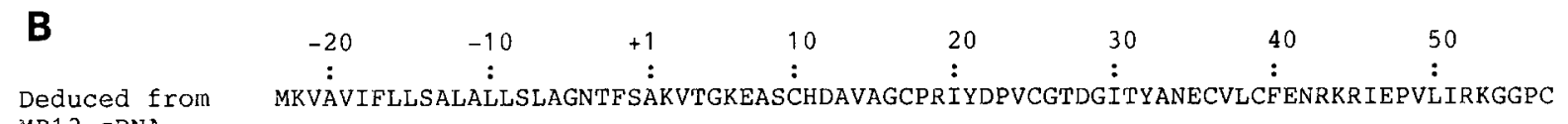

(New sequence deduced from Peak b protein) IYDPV-GRDGITYANE-VL-FENRKRIEPV

FIG. 5. (A) The nucleotide sequences of MP12 cDNA from Mills et al. (16). Bold characters indicate the primer pair used for PCR of this work and bars indicate the initial and stop codons of the open reading frame. (B) Comparison of amino acid sequences deduced from MP12 cDNA with those determined from Edman degradation of peak a and peak b proteins purified from HPLC shown in Fig. 1.

human PSTI (32), locates three-dimensionally opposite to the reactive site. The result of sequence analysis for peak $b$ protein reveals that the immobilized trypsin linked to Affi-Gel 10 is able to digest only the bound inhibitor at the reactive site but is inaccessible to attack the basic sequence. The peak $b$ protein is hiologically inactive, which is contradictory to previous reports that one cleavage only at the reactive site of either porcine or bovine PSTI did not result in their denaturation $(28,34)$.

Our results suggest that MSVS TI corresponds to MP12 cDNA. A question arises whether MSVS TI and P12 are the same protein. The molecular size of a protein deduced from MP12 cDNA should be smaller than that of P12 protein; note that the 80 amino-acid open reading frame of the cDNAs should generate a primary translation product of $9 \mathrm{kDa}$, which could decrease in size after removal of the signal peptide to $7 \mathrm{kDa}$, which is the molecular size of MSVS TI. Glycosylation of the 7-kDa core protein to produce $\mathrm{P} 12$ protein as suggested by Mills et $a l$. $(16,17)$ was not observed here. Perhaps glycosylation of the P12 occurs only in the prostate, but not in the seminal vesicle. Obviously, MSVS TI is different from the P12 protein.

The signal peptides of both MSVS TI and rat PSTI-II have 23 amino acids, with sequences that are almost identical. While the $\mathrm{NH}_{2}$-terminal residue of rat PSTI-II is Lys, that of MSVS TI is Ala, which agrees with the suggestion of Mills et al. (16) from analysis of MP12 cDNA by a weight-matrix method of von Heijne (35) for predicting the signal peptide sequence cleavage site. Appar- ently, post-translational cleavage must be at the peptide bond of Ser-Ala in the signal peptide of MSVS TI and at the peptide bond of Ala-Lys in the signal peptide of rat PSTI-II.

\section{ACKNOWLEDGMENTS}

This work was partially supported by the National Science Council, Taiwan, Republic of China (Grant NSC-80-0203-B001-05). Some of the work described in this paper forms part of a dissertation submitted by M.-L. Lai in partial fulfillment for the requirement of the degree of D.Sc. at National Taiwan University.

\section{REFERENCES}

1. Mann, T. (1964) The Biochemistry of Semen and of the Male Reproductive Tract, Wiley, New York.

2. Price, D., and Williams-Ashman, H. G. (1961) in Sex and Internal Secretion (Young, W. C., Ed.), 3rd ed., Vol 1, pp. 366-448, Williams \& Wilkins, Baltimore.

3. Pang, S. F., Chow, P. H., and Wang, T. M. (1979) J. Reprod. Fertil. 56, $129-132$.

4. Peitz, B., and Olds-Clarke, P. (1986) Biol. Reprod. 35, 608-617.

5. Ostrowski, M. C., Kistler, M. K., and Kistler, W. S. (1979) J. Biol. Chem. 254, 383-390.

6. Chen, Y. H., Pentecost, B. T., McLachlan, J. A., and Teng, C. T. (1987) Mol. Endocrinol. 1, 707-716.

7. Higgins, S. F., Burchell, J. M., and Mainwaring, I. P. (1976) Biochem. J. 158, 271-282.

8. Higgins, S. F., Colman, A., Fuller, F. M., and Jackson, P. J. (1981) Mol. Cell Endocrinol. 21, 255-262.

9. Uda, K. I., Ogawa, M., Shibata, T., Murata, A., Mori, T., Kikuchi, N., Yoshida, N. Tsunasawa, S., and Sakiyama, F. (1988) Biol. Chem. Hoppe-Seyler 369(Suppl), 55-61. 
10. Fink, E., and Fritz, H. (1976) in Methods in Enzymology (Jakoby, W. B., and Wilchek, M., Eds.), Vol. 46, pp. 825-833, Academic Press, San Diego.

11. Fritz, H., Tschesche, H., and Fink, E. (1976) in Methods in Enzymology (Jakoby, W. B., and Wilchek, M., Eds.), Vol. 46, pp. 834847, Academic Press, San Diego.

12. Meloun, B., Čechová, D., and Jonáková, V. (1984) Hoppe-Seyler's Z. Physiol. Chem. Bd. 364(Suppl.), 1665-1670.

13. Tschesche, H., Wittig, B., Decker, G., Müller-Esterl, W., and Fritz, H. (1982) Eur. J. Biochem. 126, 99104

14. Huhtala, M. L. (1984) Hoppe-Seyler's Z. Physiol. Chem. Bd. 365(Suppl.), 819-825.

15. Čechová, D., and Jonáková, V. (1981) in Methods in Enzymology (Lorand, L., Ed.), Vol. 80, pp. 792-803, Academic Press, San Diego.

16. Mills, J. S., Needham, M., and Parker, M. G. (1987) EMBO J. 6, 3711-3717.

17. Mills, J. S., Needham, M., Thompson, T. C., and Parker, M. G. (1987) Mol. Cell. Endocrinol. 53, 111-118.

18. Schägger, H., and von Jagow, G. (1987) Anal. Biochem. 166, 368379

19. Tsugita, A., Uchida, T., Mewes, H. W., and Ataka, T. (1987) $J$. Biochem. 102, 1593-1597.

20. Spackman, D. H., Stein, W. H., and Moore, S. (1958) Anal. Chem. 30, 1190-1206.

21. Green, N. M., and Work, F. (1958) Binchem .J. 54, 347-352.
22. Lottenberg, R., Christensen, U., Jackson, C. M., and Coleman, P. L. (1981) in Methods in Enzymology (Lorand, L., Ed.), Vol. 80, pp. 341-361, Academic Press, San Diego.

23. Dixon, M. (1972) Biochem. J. 129, 197-202.

24. Greco, W. R., and Hakala, M. T. (1979) J. Biol. Chem. 254, 12,104$12,109$.

25. Maniatis, T., Fritsch, E. F., and Sambrook, J. (1989) Molecular Cloning: A Laboratory Manual. Cold Spring Harbor Laboratory Press, Cold Spring Harbor, NY.

26. Chung, C. T., Niemela, S. L., and Miller, R. H. (1989) Proc. Natl. Acad. Sci. USA 86, 2172-2175.

27. Tabor, S., and Richardson, C. C. (1987) Proc. Natl. Acad. Sci. USA 84, 4767-4771.

28. Schneider, S. L., Stasiuk, L., and Laskowski, M., Sr. (1973) J. Biol. Chem. 248, 7207-7214.

29. Bartelt, D. C., and Greene, L. J. (1971) J. Biol. Chem. 246, 22182229.

30. Horii, A., Tomita, N., Yokouchi, H., Doi, S., Uda, K., Ogawa, M., Mori, T., and Matsubara, K. (1989) Biochem. Biophys. Res. Commun. 162, 151-159

31. Hill, R. E., and Hastie, N. D. (1987) Nature 326, 96-99.

32. Kikuchi, N., Negata, K., Shin, M., Mitsushima, K., Teraoka, H., and Yoshida, N. (1989) J. Biochem. 106, 1059-1063.

33. Bolognesi, M., and Gatti, G. (1982) J. Mol. Biol. 162, 839-868.

34. Sealock, R. W., and Laskowski, M., Jr. (19/3) Biochemistry 12, 3139-3146.

35. von Heijne, G. (1986) Nucleic Acids Res. 14, 4683-4690. 